\title{
Gradient High Performance Liquid Chromatography Method Development and Validation for Simultaneous Determination of Phenylephrine and Ibuprofen in Tablet Dosage Form
}

\author{
Venkata Raveendra Babu Vemula ${ }^{1 *}$ and Pankaj Kumar Sharma \\ ${ }^{1}$ Faculty of Pharmacy, Pacific Academy of Higher Education and Research University, Udaipur-313024, ${ }^{2}$ School of \\ Pharmaceutical Sciences, Jaipur National University, Jaipur-302025, Rajasthan, India
}

${ }^{*}$ For correspondence: Email: raveendra.vemula@gmail.com; Tel: 91+9705126244

Received: 16 June 2013

Revised accepted: 17 March 2014

\begin{abstract}
Purpose: To develop a gradient high performance liquid chromatography (HPLC) method for the simultaneous determination of phenylephrine (PHE) and ibuprofen (IBU) in solid dosage form.

Methods: HPLC determination was carried out on an Agilent XDB C-18 column $(4.6 \times 150 \mathrm{~mm}, 5 \mu$ particle size) with a gradient mobile phase composed of $0.1 \%$ orthophosphoric acid and acetonitrile at a ratio of: 0.01/95/5, 2.5/95/5, 6/10/90, 8/10/90, 8.1/95/5 and 13/95/5 for time (min)/0.1\% orthophosphoric acid (\%)/acetonitrile (\%) at a flow rate of $1.0 \mathrm{~mL} / \mathrm{min}$. Column temperature was maintained at $30{ }^{\circ} \mathrm{C}$ and detection was carried out using a photodiode array (PDA) detector at $210 \mathrm{~nm}$. Validation parameters, including system suitability, linearity, precision, accuracy, specificity, limit of detection (LOD), limit of quantification (LOQ), stability of sample and standard stock solutions as well as robustness were obtained as per International Conference on Harmonization (ICH) guidelines. The proposed method was applied to the determination of phenylephrine and ibuprofen in commercial tablets.

Results: Retention time for phenylephrine and ibuprofen were 2.7 and $8.4 \mathrm{~min}$, respectively while \% recovery was 99.42 and $99.80 \%$, respectively. The relative standard deviation (\% RSD) for assay of the tablets was $<2 \%$.

Conclusion: The method is fast, accurate, precise and sensitive, and hence it can be employed for routine quality control of tablets containing both drugs in quality control (QC) laboratories and pharmaceutical industry.
\end{abstract}

Keywords: Phenylephrine, Ibuprofen, Simultaneous determination, Validation, Gradient HPLC.

Tropical Journal of Pharmaceutical Research is indexed by Science Citation Index (SciSearch), Scopus, International Pharmaceutical Abstract, Chemical Abstracts, Embase, Index Copernicus, EBSCO, African Index Medicus, JournalSeek, Journal Citation Reports/Science Edition, Directory of Open Access Journals (DOAJ), African Journal Online, Bioline International, Open-J-Gate and Pharmacy Abstracts

\section{INTRODUCTION}

Phenylephrine (PHE) is chemically named as (R)-3-[-1-hydroxy-2-(methylamino) ethyl] phenol (Figure $1 \mathrm{~A})$. It is a nasal decongestant which helps to relieve a blocked nose. It reduces the size of the blood vessels in the nose and sinuses thus enabling one to breathe more easily. It is also used as paroxysmal supraventricular tachycardia, mydriasis, and haemorrhoids [1]. Ibuprofen (IBU) is chemically named as (RS)-2(4-(2-methylpropyl) phenyl) propanoic acid (Figure 1B). It is used to relieve symptoms of a wide range of illnesses such as headaches, backache, pains, migraine, cold and flu symptoms and arthritis. Its effects are due to the inhibitory actions on cyclo-oxygenases, which are involved in the synthesis of prostaglandins. 
Prostaglandins have an important role in the production of pain, inflammation and fever [2].<smiles>CNC[C@H](O)c1cccc(O)c1</smiles>

(a)<smiles>CC(C)Cc1ccc([C@@H](C)C(=O)O)cc1</smiles>

(b)

Figure 1: Structure of (a) Phenylephrine and (b) Ibuprofen

Various ultra violet (UV) and HPLC assay methods have been reported in the literature for the determination of phenylephrine [3-6] and ibuprofen [7-11] individually and in-combination with other drugs. According to the literature, there is no official method for the simultaneous determination of both drugs by reverse phase HPLC in combined tablet dosage forms. Hence, an attempt has been made to develop new method for simultaneous determination [12-14] and validation of phenylephrine and ibuprofen in a tablet formulation in accordance with $\mathrm{ICH}$ guidelines [15-17].

\section{EXPERIMENTAL}

\section{Instrumentation}

Chromatography was performed with Water's 2695 HPLC systems provided with Hamilton syringe, auto sampler and 2996 photodiode array detector. All HPLC systems were equipped with a column compartment with temperature control and an on-line degasser. Data acquisition, analysis, and reporting were performed by Empower2 (Waters) chromatography software.

\section{Reagents and chemicals}

The reference samples of PHE and IBU were provided as gifts from Spectrum Pharma research solutions, Hyderabad. HPLC grade acetonitrile, HPLC grade methanol and all other chemicals were obtained from Merck chemical division, Mumbai. HPLC grade water obtained from Milli-Q water purification system was used throughout the study. Commercial tablets (ADVIL
- dosage: PHE - $10 \mathrm{mg}$ and IBU - $200 \mathrm{mg}$ ) were purchased from a local pharmacy.

\section{Chromatographic conditions}

The mobile phase consisted of $0.1 \%$ Ortho phosphoric acid and acetonitrile was taken in gradient ratio of time (min.) $/ 0.1 \%$ orthophosphoric acid (\%)/acetonitrile (\%) as follows: $0.01 / 95 / 5,2.5 / 95 / 5,6 / 10 / 90,8 / 10 / 90$, $8.1 / 95 / 5$ and $13 / 95 / 5$, at a flow rate of 1.0 $\mathrm{mL} / \mathrm{min}$. Agilent XDB C-18 column (4.6 × 150 $\mathrm{mm}, 5 \mu$ particle size) was used as the stationary phase. Although the PHE and IBU have different $\lambda$ max, but considering the chromatographic parameter, sensitivity and selectivity of method for both drugs, $210 \mathrm{~nm}$ was selected as the detection wavelength for PDA detector.

\section{Preparation of standard stock solution}

Standard stock solutions were prepared by transferring $10 \mathrm{mg}$ of phenylephrine and 200 $\mathrm{mg}$ of ibuprofen into a clean and dry $100 \mathrm{~mL}$ volumetric flask, to which $70 \mathrm{~mL}$ of diluent was added, sonicated for $5 \mathrm{~min}$ and volume made up to $100 \mathrm{~mL}$ with diluent to get stock solution.

\section{Preparation of working standard solutions}

Aliquot of $0.5,0.75,1.0,1.25,1.5 \& 2.5 \mathrm{~mL}$ pipette out from stock solution into $10 \mathrm{~mL}$ volumetric flask separately for both PHE and IBU and volume was made up to $10 \mathrm{~mL}$ with diluent. This gives the solutions of $5,7.5,10,12.5,15$ and $25 \mu \mathrm{g} / \mathrm{mL}$ for phenylephrine and 100, 150, 200, 250, 300 and $500 \mu \mathrm{g} / \mathrm{mL}$ for ibuprofen, respectively.

\section{Sample preparation}

Twenty tablets were weighed and crushed into fine powder. An amount of the powder equivalent to the weight of five tablets was taken and dissolved in $1000 \mathrm{~mL}$ diluent, sonicated for 20 min and filtered through PVDF $0.45 \mu$ filter. From the filtrate, $1 \mathrm{~mL}$ was pipetted into a $10 \mathrm{~mL}$ volumetric flask and the solution made up to the volume with the diluent.

\section{Method validation}

\section{System suitability test}

To ensure that the resolution and reproducibility of the HPLC system was adequate for the analysis, a system suitability test was established. Data from six injections of $10 \mu \mathrm{L}$ of the working standard solutions of PHE and IBU were used for the evaluation of the system 
suitability parameters like tailing factor, the number of theoretical plates, retention time and resolution factor.

\section{Linearity}

By appropriate aliquots of the standard PHE and IBU solutions with the mobile phase, six working solutions ranging between $5-25 \mu \mathrm{g} / \mathrm{mL}$ of $\mathrm{PHE}$ and $100-500$ of IBU $\mu \mathrm{g} / \mathrm{mL}$ were prepared. The linearity point of each experiment was performed in triplicate according to the optimized chromatographic conditions. The peak areas of the chromatograms were plotted against the concentration of PHE and IBU to obtain the calibration curve.

\section{Accuracy}

Recovery studies by the standard addition method were performed with a view to justify the accuracy of the proposed method. Previously analyzed samples of PHE and IBU to which known amounts of standard PHE and IBU corresponding to 50, 100 and $150 \%$ of target concentration, were added. The accuracy was expressed as the percentage of analyte recovered by the proposed method.

\section{Precision}

Precision was determined as repeatability and intermediate precision (ruggedness), in accordance with $\mathrm{ICH}$ guidelines. The intra-day and inter-day precision were determined by analyzing the samples of PHE and IBU. Determinations were performed on the same day as well as well as on consequent days.

\section{Limit of detection and the limit of quantification}

Limit of detection (LOD) and limit of quantification (LOD) of PHE and IBU were determined by calibration curve method. Solutions of both PHE and IBU were prepared in linearity range and injected in triplicate. Average peak area of three analyses was plotted against concentration. LOD and LOQ were calculated by using following equations: $\mathrm{LOD}=(3.3 \times \mathrm{Syx}) / \mathrm{b}, \mathrm{LOQ}=(10.0 \times$ Syx $) / b$, where Syx is residual variance due to regression and $b$ is slope.

\section{Robustness}

The robustness of the method was performed by deliberately changing the chromatographic conditions. Organic strength was varied by \pm 5 $\%$, column temperature by $\pm 5^{\circ} \mathrm{C}$ and flow rate by $\pm 0.1 \mathrm{~mL}$.

\section{Stability}

The sample and standard solutions were injected at $0 \mathrm{~h}$ (control) and after $24 \mathrm{~h}$ (stability sample) at ambient room temperature. Stability was determined by determining RSD for sample and standard solutions.

\section{Statistical analysis}

Where applicable, results were expressed as mean \pm SD. $\%$ RSD and data were analyzed statistically by using t- test with aid of Microsoft Excel-2007 software and data were considered significantly different at $p \leq 0.05$.

\section{RESULTS}

\section{Method development}

Initially reverse phase liquid chromatography separation was tried using various ratios of methanol and water, acetonitrile and water as mobile phases, in which both the drugs did not responded properly, and the resolution was also poor. The organic content of mobile phase was also investigated to optimize the separation of both drugs.

To improve the tailing factor, the $\mathrm{pH}$ of mobile phase became an important factor. At $\mathrm{pH} 3$, both drugs eluted with better separation. Thereafter, buffer: acetonitrile were taken in gradient: $T$ (min)/ \%buffer / \% acetonitrile: 0.01/95/5, 2.5/95/5, 6/10/90, 8/10/90, 8.1/95/5 and 13/95/5 using a flow rate of $1.0 \mathrm{~mL} / \mathrm{min}$. Agilent XDB C18 column $(4.6 \times 150 \mathrm{~mm}, 5 \mu$ particle size $)$ was selected as the stationary phase to improve resolution and the tailing of both peaks were reduced considerably and brought close to 1 .

To analyze both drugs, detection was tried at various wavelengths from $205 \mathrm{~nm}$ to $280 \mathrm{~nm}$. Both PHE and IBU showed maximum absorption at a wavelength of $210 \mathrm{~nm}$, which was selected as the detection wavelength for PDA detector. The retention times were found to about $2.7 \mathrm{~min}$ and $8.4 \mathrm{~min}$ for PHE and IBU, respectively. The chromatogram obtained was shown in the Figure 2.

\section{Method validation}

\section{System suitability}

System suitability parameters such as number of theoretical plates, peak tailing, retention time and resolution factor were determined. The total run time required for the method is only $13 \mathrm{~min}$ for 


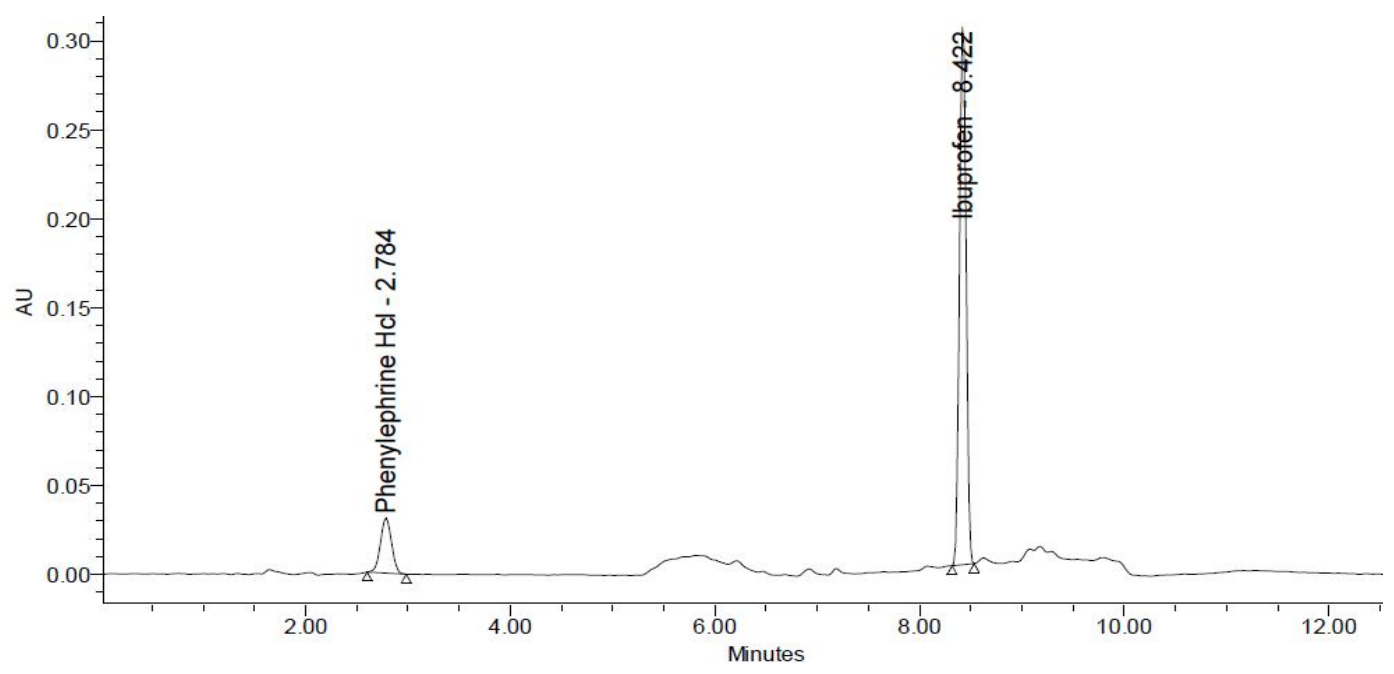

Figure 2: Representative chromatogram of phenylephrine and ibuprofen

Table 2: Accuracy for PHE and IBU

\begin{tabular}{|c|c|c|c|c|c|c|c|}
\hline \multicolumn{2}{|c|}{$\begin{array}{l}\text { Preanalysed sample } \\
\text { solution concentration } \\
(\mu \mathrm{g} / \mathrm{mL})\end{array}$} & \multicolumn{2}{|c|}{$\begin{array}{l}\text { Standard drug } \\
\text { concentration } \\
(\mu \mathrm{g} / \mathrm{mL})\end{array}$} & \multicolumn{2}{|c|}{$\begin{array}{l}\text { Amount recovered } \\
(\mu \mathrm{g} / \mathrm{mL})\end{array}$} & \multicolumn{2}{|c|}{ Recovery (\%) } \\
\hline PHE & IBU & PHE & $I B U$ & PHE & IBU & PHE & IBU \\
\hline 10 & 200 & 5 & 100 & 4.9 & 100.7 & 98.7 & 100.7 \\
\hline 10 & 200 & 5 & 100 & 4.9 & 100.7 & 98.1 & 100.7 \\
\hline 10 & 200 & 5 & 100 & 5.1 & 100.8 & 101.0 & 100.8 \\
\hline 10 & 200 & 10 & 200 & 9.8 & 203.0 & 98.1 & 101.5 \\
\hline 10 & 200 & 10 & 200 & 9.8 & 201.9 & 98.0 & 100.9 \\
\hline 10 & 200 & 10 & 200 & 9.9 & 203.5 & 99.0 & 101.7 \\
\hline 10 & 200 & 15 & 300 & 15.1 & 300.5 & 100.9 & 100.2 \\
\hline 10 & 200 & 15 & 300 & 15.0 & 298.9 & 100.0 & 99.6 \\
\hline \multirow[t]{4}{*}{10} & 200 & 15 & 300 & 14.9 & 299.3 & 99.6 & 99.8 \\
\hline & & & & & Mean & 99.27 & 100.66 \\
\hline & & & & & SD & 1.197 & 0.705 \\
\hline & & & & & $\%$ RSD & 1.2 & 0.7 \\
\hline
\end{tabular}

eluting both PHE and IBU. The results obtained are shown in Table1.

Table 1: System suitability of PHE and IBU

\begin{tabular}{lcc}
\hline Variable & PHE & IBU \\
\hline No. of theoretical plates & 3036 & 77131 \\
Tailing factor & 1.03 & 1.03 \\
Resolution factor & \multicolumn{2}{c}{36.4} \\
Retention time & $2.7 \mathrm{~min}$ & $8.4 \mathrm{~min}$ \\
Mean area & 232598.0 & 1367853.7 \\
RSD & 0.9 & 0.1 \\
\hline
\end{tabular}

\section{Linearity}

PHE showed a linearity of response between 5 $25 \mu \mathrm{g} / \mathrm{mL}$ and IBU showed a linearity of response between $100-500 \mu \mathrm{g} / \mathrm{mL}$. These were represented by a linear regression equations as follows: $\mathrm{y}(\mathrm{PHE})=22901 \mathrm{x}+6949\left(\mathrm{r}^{2}=\right.$ $0.999) ; y(I B U)=7079 . x-1586\left(r^{2}=0.999\right)$ and regression line was established by least squares method; correlation coefficient $\left(r^{2}\right)$ for PHE and IBU was $>0.98$. Hence, the curves were linear.

\section{Accuracy}

To pre-analyzed sample solution, a definite concentration of standard drug (50,100 and 150 $\%$ level) was added and recovery was studied. The percentage Mean recovery for PHE and IBU are 99.27 and $100.66 \%$, respectively and these results are within acceptable limit of $98-102 \%$. The \% RSD for PHE and IBU are 1.2 and 0.7, respectively and the percentage RSD for PHE and IBU is within limit of $\leq 2$. Hence the proposed method is accurate and the results were summarized in Table 2.

\section{Precision}

\section{Repeatability}

Six replicates injections in same concentration were analyzed in the same day for repeatability 
and the \% RSD for PHE and IBU were found to be 1.1 and 1.0, respectively and which is for PHE and IBU found to be within the acceptable limit of $\leq 2$ and hence, the method is reproducible as presented in Table 3.

\section{Intermediate precision}

Six replicates injections in same concentration were analyzed on two different days with different analyst and column for verifying the variation in the precision and the \% RSD for PHE and IBU was 0.3 and 1.3, respectively, and is within the acceptable limit of $\leq 2$. The overall $\%$ RSD for PHE and IBU was found to be 0.8 and 1.1 , respectively, and it is within the acceptable limit of $\leq 2$ and hence, the method is reproducible on different days with different analyst and column and the results are as shown in Table 3.
Statistical Analysis of Precision Result: Probability value $(P)$ for PHE and IBU at $5 \%$ significance level was found to be 0.75 and 0.68 , respectively, which are greater than 0.05 and hence no significant difference was observed in the precision results carried out for two consecutive days, and the results are shown in Table 4.

\section{Robustness}

The robustness was established by changing the flow rate, column temperature and composition of the mobile phase within allowable limits from actual chromatographic conditions. It was observed that there were no marked change in mean RT and RSD is within limit of $\leq 2$. The tailing factor, resolution factor and number of theoretical plates were found to be within

Table 3: Precision data for PHE and IBU

\begin{tabular}{|c|c|c|c|}
\hline Validation parameter & Sample no. & PHE & IBU \\
\hline \multirow{4}{*}{$\begin{array}{l}\text { Repeatability } \\
\text { (Day1, Analyst 1) }\end{array}$} & 1 & 237093 & 1382263 \\
\hline & 2 & 237444 & 1398591 \\
\hline & 3 & 239179 & 1357440 \\
\hline & 4 & 235016 & 1383691 \\
\hline \multirow{12}{*}{$\begin{array}{l}\text { Intermediate precision } \\
\text { (Day 2, Analyst 2) }\end{array}$} & 5 & 231882 & 1370765 \\
\hline & 6 & 234674 & 1376931 \\
\hline & Mean & 235881.33 & 1378280.2 \\
\hline & SD & 2568.49 & 13786.08 \\
\hline & $\%$ RSD & 1.1 & 1.0 \\
\hline & 1 & 236742 & 1381213 \\
\hline & 2 & 236010 & 1347947 \\
\hline & 3 & 235070 & 1358811 \\
\hline & 4 & 236706 & 1380356 \\
\hline & 5 & 236243 & 1384521 \\
\hline & 6 & 236592 & 1394036 \\
\hline & Mean & 236227.2 & 1374480.7 \\
\hline \multirow{5}{*}{$\begin{array}{l}\text { Global statistics (Inter day } \\
\text { precision) }\end{array}$} & SD & 634.65 & 17393.32 \\
\hline & $\%$ RSD & 0.3 & 1.3 \\
\hline & Overall Mean & 236054.3 & 1376380.4 \\
\hline & SD & 1792.88 & 15094.33 \\
\hline & Overall \% RSD & 0.8 & 1.1 \\
\hline
\end{tabular}

$S D=$ standard deviation $R S D=$ relative standard deviation

Table 4: Students t-test data for precision of results for PHE and IBU

\begin{tabular}{lcccc}
\hline $\begin{array}{l}\text { Validation } \\
\text { parameter }\end{array}$ & $\begin{array}{c}\text { Mean } \\
\text { response }\end{array}$ & Probability, $\boldsymbol{P ( \geq 0 . 0 5 )}$ & $\begin{array}{c}\text { Mean } \\
\text { response }\end{array}$ & Probability $\boldsymbol{P ( \geq 0 . 0 5 )}$ \\
\hline Repeatability -Day 1 & 235881.3 & 0.75 & 1378280.2 & 0.68 \\
$\begin{array}{l}\text { Intermediate } \\
\text { precision - Day 2 }\end{array}$ & 236227.1 & & 1374480.7 & \\
\hline
\end{tabular}


Table 5: Robustness data for PHE

\begin{tabular}{|c|c|c|c|c|c|c|}
\hline \multirow{2}{*}{$\begin{array}{l}\text { Analytical } \\
\text { conditions } \\
\text { Evaluation } \\
\text { parameters }\end{array}$} & \multicolumn{2}{|c|}{$\begin{array}{l}\text { Flow rate } \\
\text { (ml/min) }\end{array}$} & \multicolumn{2}{|c|}{ Column temperature $\left({ }^{\circ} \mathrm{C}\right)$} & \multicolumn{2}{|c|}{$\begin{array}{l}\text { Mobile phase } \\
\text { composition }\end{array}$} \\
\hline & 1.1 & 0.9 & 35 & 25 & $+5 \%$ & $-5 \%$ \\
\hline Mean RT & 2.29 & 2.69 & 2.17 & 2.31 & 2.0 & 2.8 \\
\hline Mean area & 189917 & 213938 & 252511 & 2.2985 & 204678 & 234264 \\
\hline SD & 3557 & 6294.984 & 4590 & 3583 & 3575 & 4168 \\
\hline RSD\% & 1.9 & 2.9 & 1.8 & 1.7 & 1.7 & 1.8 \\
\hline Tailing factor & 1.11 & 1.08 & 0.97 & 1.03 & 1.02 & 1.0 \\
\hline $\begin{array}{l}\text { No. of theore- } \\
\text { tical plates }\end{array}$ & 3017 & 3154 & 2719 & 2731 & 5910 & 3050 \\
\hline
\end{tabular}

Table 6: Results of Robustness for IBU

\begin{tabular}{|c|c|c|c|c|c|c|}
\hline \multirow{2}{*}{$\begin{array}{l}\text { Analytical } \\
\text { conditions } \\
\text { Evaluation } \\
\text { parameters }\end{array}$} & \multicolumn{2}{|c|}{ Flow rate (ml/min) } & \multicolumn{2}{|c|}{$\begin{array}{c}\text { Column temperature } \\
\left({ }^{\circ} \mathrm{C}\right)\end{array}$} & \multicolumn{2}{|c|}{$\begin{array}{c}\text { Mobile phase } \\
\text { composition }\end{array}$} \\
\hline & 1.1 & 0.9 & 35 & 25 & $+5 \%$ & $-5 \%$ \\
\hline Mean RT & 8.17 & 8.50 & 8.31 & 8.31 & 8.31 & 8.43 \\
\hline Mean area & 1288586 & 1463597 & 1368963 & 1344180 & 2662752 & 1367854 \\
\hline SD & 6252.5 & 2999 & 22732 & 2499 & 32229 & 1333 \\
\hline RSD\% & 0.5 & 0.2 & 1.7 & 0.2 & 1.2 & 0.1 \\
\hline Tailing factor & 1.01 & 1.01 & 1.01 & 1.00 & 1.01 & 1.02 \\
\hline $\begin{array}{l}\text { No. of theoretical } \\
\text { plates }\end{array}$ & 71459 & 72979 & 78646 & 75429 & 74417 & 73614 \\
\hline
\end{tabular}

acceptable limits for both PHE and IBU. Hence, the method is reliable with variations in the analytical conditions and the results for PHE are shown in Table 5 while the results for IBU are shown in Table 6.

\section{Stability of sample solution}

The sample and standard solutions were injected at $0 \mathrm{~h}$ (comparison sample) and after $24 \mathrm{~h}$ (stability sample) at ambient room temperature $30{ }^{\circ} \mathrm{C}$. The RSD for $0 \mathrm{~h}$ and $24 \mathrm{~h}$ for sample and standard solutions of PHE are 1.1, 0.2 and 1.8, 0.3 , respectively. The RSD of 0 and $24 \mathrm{~h}$ for sample and standard solutions of IBU are 1.0, 1.0 and $0.1,1.3$, respectively. RSD results for both PHE and IBU are within the acceptable limits of $\leq 2$ and hence, the sample and standard stock are stable for $24 \mathrm{~h}$ in ambient room temperature and the results are shown in Table 7.

\section{$L O D$ and $L O Q$}

LOD and LOQ for PHE were 0.03895 and $0.11803 \mu \mathrm{g} / \mathrm{mL}$ respectively, and LOD and LOQ for IBU were 0.338187 and $1.024809 \mu \mathrm{g} / \mathrm{mL}$, respectively.

\section{Results of method application to tablet}

The content of PHE and IBU in the tablets was found by the proposed method and the results were shown in Table 8.

\section{DISCUSSION}

RP-HPLC method was developed and validated for the simultaneous determination of phenylephrine and ibuprofen in tablet dosage form. The resolution between two peaks is always more than 2 . The system suitability tests revealed that numbers of theoretical plates were above 2000 and tailing factor is less than 2. PHE and IBU showed a linearity of response between5-25 $\mathrm{\mu g} / \mathrm{ml}$ and $100-500 \mu \mathrm{g} / \mathrm{ml}$. The mean peak area of the chromatograms was plotted against the concentration of PHE and IBU to obtain the calibration curve. Linearity was high as well as recovery of PHE and IBU, indicating high accuracy of the method. Repeatability and intermediate precision values were within the acceptable limits. This indicates that the method is precise. Specificity experiment shows that there is no interference or overlapping of the peaks of excipients or diluents with the main peaks of PHE and IBU. The lowest values of LOD and LOQ as obtained by the proposed method indicate that the method is sensitive. The stability studies indicate that both 
Table 7: Sample and standard stock solution stability data for PHE and IBU

\begin{tabular}{|c|c|c|c|c|c|c|c|c|}
\hline \multirow{3}{*}{$\begin{array}{l}\text { Conc. } \\
\text { (ug/ml) } \\
\text { Injection no. }\end{array}$} & \multicolumn{4}{|c|}{ Phenylephrine } & \multicolumn{4}{|c|}{ Ibuprofen } \\
\hline & \multicolumn{2}{|c|}{$\begin{array}{c}\text { Sample stock solution } \\
\text { area }\end{array}$} & \multicolumn{2}{|c|}{$\begin{array}{l}\text { Standard stock } \\
\text { solution area }\end{array}$} & \multicolumn{2}{|c|}{$\begin{array}{c}\text { Sample stock solution } \\
\text { area }\end{array}$} & \multicolumn{2}{|c|}{$\begin{array}{l}\text { Standard stock } \\
\text { solution area }\end{array}$} \\
\hline & $\begin{array}{l}\mathrm{Oh} \\
\text { day1 }\end{array}$ & After $24 \mathrm{~h}$ & 0 h-day1 & After $24 \mathrm{~h}$ & 0 h-Day1 & After $24 \mathrm{~h}$ & 0 h-Day1 & After $24 \mathrm{~h}$ \\
\hline 1 & 237093 & 237052 & 230261 & 236742 & 1382263 & 1382261 & 1367303 & 1381213 \\
\hline 2 & 237444 & 237146 & 231405 & 236010 & 1398591 & 1398572 & 1369168 & 1347947 \\
\hline 3 & 239179 & 238212 & 232703 & 235070 & 1357440 & 1357462 & 1365533 & 1358811 \\
\hline 4 & 235016 & 237457 & 241727 & 236706 & 1383691 & 1383635 & 1369027 & 1380356 \\
\hline 5 & 231882 & 238013 & 236179 & 236243 & 1370765 & 1370732 & 1368168 & 1384521 \\
\hline 6 & 234674 & 237126 & 233313 & 236592 & 1376931 & 1376645 & 1367923 & 1394036 \\
\hline Mean & 235881.3 & 237501.0 & 234264.7 & 236227.2 & 1378280 & 1378217.8 & 1367854 & 1374481 \\
\hline SD & 2568.493 & 497.56 & 4169.00 & 634.65 & 13786.08 & 13778.98 & 1333.90 & 17393.32 \\
\hline$\%$ RSD & 1.1 & 0.2 & 1.8 & 0.3 & 1.0 & 1.0 & 0.1 & 1.3 \\
\hline
\end{tabular}

Table 8: Results of HPLC Analysis of Tablet for PHE and IBU

\begin{tabular}{|c|c|c|c|c|c|c|}
\hline $\begin{array}{l}\text { No. of } \\
\text { sample } \\
\text { assayed }\end{array}$ & $\begin{array}{l}\text { Label amount } \\
\text { (mg) }\end{array}$ & $\begin{array}{l}\text { Amount found } \\
\text { (mg) }\end{array}$ & $\%$ Assay ( & lean \pm SD) & & \\
\hline 6 & $\begin{array}{c}\text { PHE } \\
10 \\
\end{array}$ & $\begin{array}{l}\text { PHE } \\
10.09 \\
\end{array}$ & $\begin{array}{c}\text { PHE } \\
100.90 \pm 1.10\end{array}$ & $\begin{array}{c}\text { IBU } \\
100.25 \pm 1.00\end{array}$ & $\begin{array}{c}\mathrm{PHE} \\
1.1 \\
\end{array}$ & $\begin{array}{l}\text { IBU } \\
1.0 \\
\end{array}$ \\
\hline
\end{tabular}

standard and sample drugs were stable up to 24 h. Change in flow rate, temperature and mobile phase composition did not cause any significant change in the results, confirming the stability of the developed method. RSD for precision was < $2 \%$ which confirms that method is sufficiently precise. The total run time required for the method was only 13 min for eluting both phenylephrine and ibuprofen.

\section{CONCLUSION}

A new gradient HPLC method has been developed and validated for the simultaneous determination of phenylephrine and ibuprofen in tablet dosage form. The method is fast, accurate, precise and sensitive, and hence, it can be employed for routine quality control of tablets containing both drugs in quality control laboratories and industry.

\section{ACKNOWLEDGEMENT}

The authors are thankful to $\mathrm{M} / \mathrm{s}$ Spectrum Pharma Research Solutions, Hyderabad, India, for providing reference samples and other technical support for the research work.

\section{REFERENCES}

1. Chawdhary S, Angra SK, Zutshi R, Sachdev MS. Mydriasis - use of phenylephrine. Ind J Opthalmol 1984; 32(4): 213-216.
2. Rabia B, Nousheen A. An Overview of Clinical Pharmacology of Ibuprofen. Oman Med. J. 2010; 25(3): 155-161.

3. Theiaa NAS. Spectrophotometric assay of phenylephrine hydrocholride using 4-aminoantipyrine and copper (II). Pak. J. Anal. Environ. Chem. 2010; 11(1): 1-7.

4. Marin A, Garcia E, Garcia A, Barbas C. Validation of a HPLC quantification of acetaminophen, Phenylephrine and chlorpheniramine in pharmaceutical formulations: capsules and sachets. J. Pharm. Biomed. Anal. 2002; 29: 701-714.

5. Ashok K, Rishbha S, Anroop N, Gautam S. Development and validation of rp-hplc method for simultaneous estimation of nimesulide, phenylephrine Hydrochloride, chlorpheniramine maleate and caffeine anhydrous in pharmaceutical dosage form. Acta Pol. Pharm. 2012; 69(6): 1017-1022.

6. Ozan $P$, Murat $S$, Tuncel O. Simultaneous determination of paracetamol, phenylephrine hydrochloride, oxolamine citrate and chlorpheniramine maleate by HPLC in Pharmaceutical dosage forms. E. J. Chem. 2011; 8(3): 1275-1279.

7. Graham FL, John GW. High-performance liquid chromatographic determination of ibuprofen and its major metabolites in biological Fluids. J. Chromatogr. 1982; 232: 335-343.

8. Snezana SM, Gordana ZM, Aleksandra NP, Biljana BA, Valentina VZ. Quantitative analysis of ibuprofen in pharmaceuticals and Human control serum using kinetic spectrophotometry. J. Serb. Chem. Soc. 2008; 73(8-9): 879-890.

9. Ravisankar S, Vasudevan M, Gandhimathi M, Suresh B. Reversed-phase hplc method for the estimation of 
acetaminophen, ibuprofen and chlorzoxazone in formulations. Talanta, 1998; 46(6): 1577-1581.

10. Prasanna reddy B, Reddy MS. RP-HPLC method for simultaneous estimation of paracetamol and ibuprofen in Tablets. Asian J. Research Chem. 2009: 2(1): 70-72.

11. Andras S, Andrea NE, Henry TP, Bob C, Kenneth WR. A validated enantioselective assay for the determination of ibuprofen in human plasma using ultra performance liquid chromatography with tandem mass spectrometry (up/c-ms/ms). Am. J. Anal. Chem. 2010; 2: 47-58.

12. Wael AD, Ahmad AH, Kamal S, Khalid M, Eyad AN. Simultaneous High Performance Liquid Chromatographic Analysis of Oxicams in Pharmaceutical Formulations. Int. J. Pharm. 2012; 2(4): 687-695.

13. Ashraful Islam SM, Shultana S, Shahdaat Bin SM, Dewan I. UV-spectrophotometric and rp-hplc methods for the simultaneous estimation of acetaminophen and caffeine: validation, comparison and application for marketed tablet analysis. Int. J. Pharm. 2012; 2(1): 39-45.

14. RamaPrasad LA, Rao JVLNS, Srinivasu P, Vara Prasad $J$, Hemalatha J. New stability indicating hplc method for simultaneous estimation of lamivudine, tenofovir DF and nevirapine in extended release tablets. Int. J. Pharm. 2013; 3(1): 136-144.

15. International Conference on Harmonisation (ICH) of Technical Requirements for Registration of Pharmaceuticals for Human Use: Harmonised Triplicate Guideline on Validation of Analytical Procedures: Methodology, IFPMA, Switzerland, 1996.

16. The British Pharmacopoeia. London: Her Majesty's Stationery Office, 2007.

17. Beckett AH, Stenlake JB. Practical Pharmaceutical Chemistry. 4th ed., New Delhi: CBS Publishers and Distributors; 2002; $p 157$. 